Historic, Archive Document

Do not assume content reflects current scientific knowledge, policies, or practices. 



\section{The True Story of}
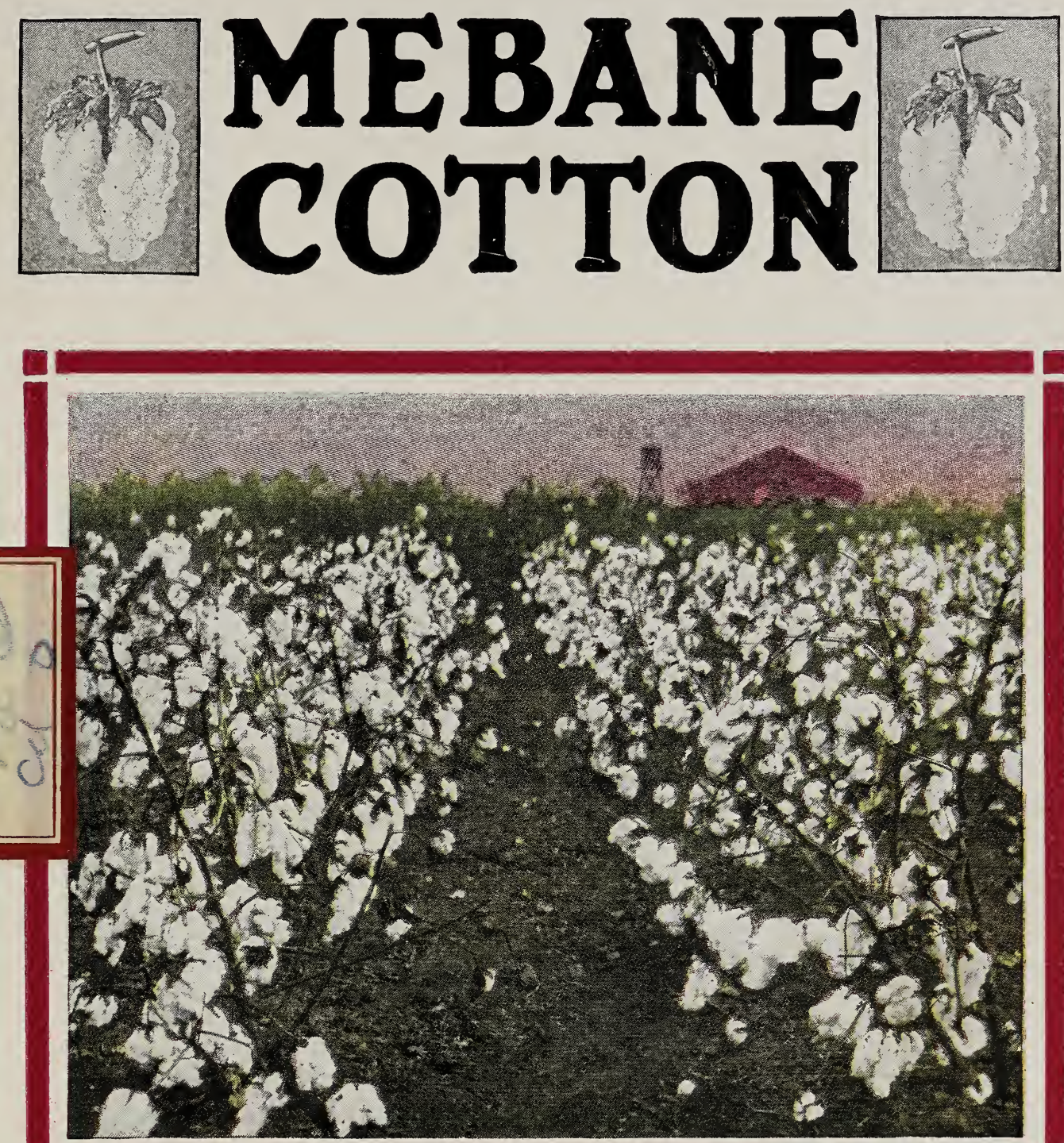

\section{A.D.MEBANE COTTON SEED CO.}

GROWERS, WHOLESALE AND RETALL DEALERS LOCKHART, TEXAS. 


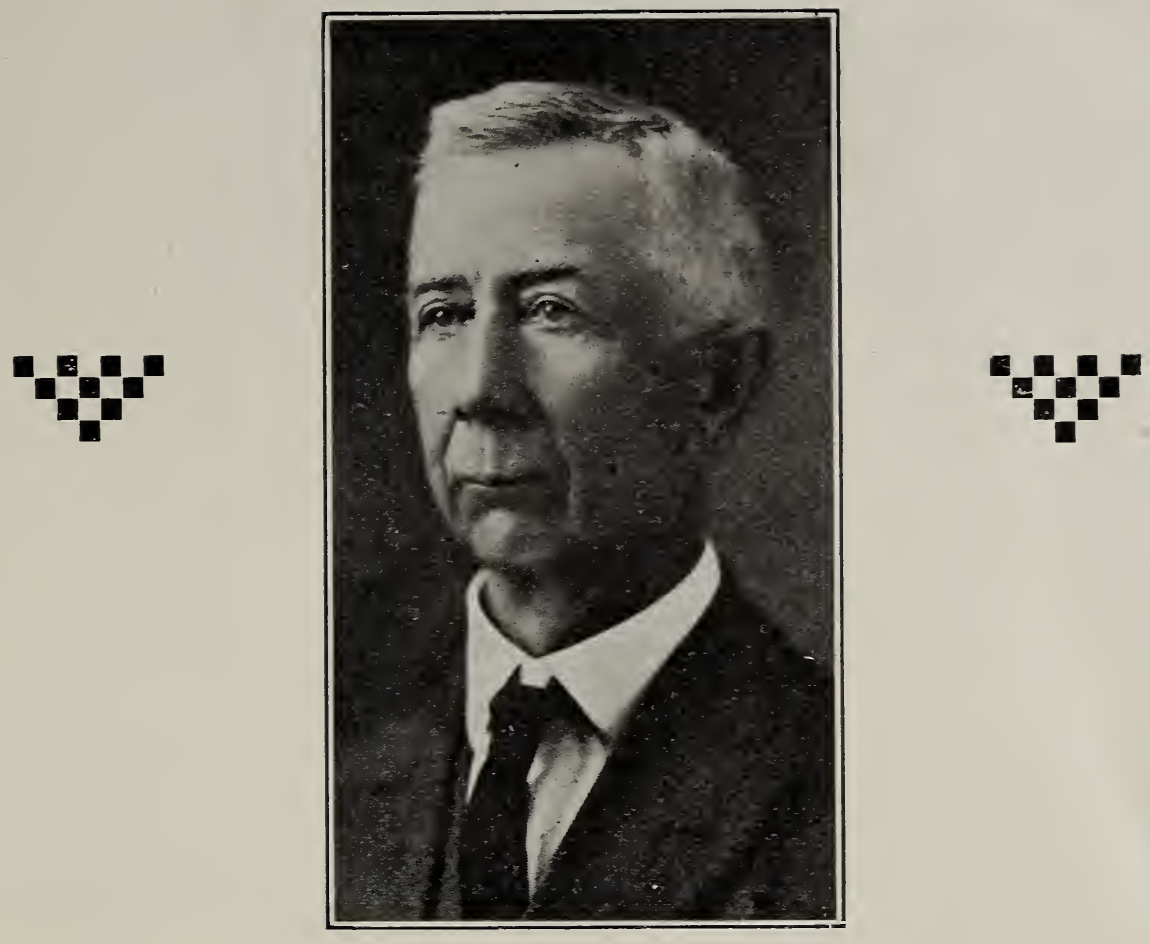

A. D. MEBANE

LOCKHART, TEXAS

Originator of Mebane Triumph Cotton

\section{Our Tenth Anniversary}

To our customers and friends:

This anniversary is approached with a feeling of pride in our record and business success and of gratitude towards those friends whose patronage and support have made this record possible.

We take advantage of the occasion to thank our old customers for their liberal patronage with the hope that it will be continued, and to those who have voluntarily given testimony of their appreciation of our Improved Mebane Triumph seed.

Naturally both from friendship and a business standpoint we are particularly anxious to make this a banner year and to give assurance to our new customers that our business principles and what we advertise are as sure to please you as well as our old customers.
A. D. Mebane Cotton Seed Co. 


\section{Origin of Mebane Triumph Cotton}

In 1882, after a storm, A. D. Mebane, the originator of Mebane Triumph Cotton, went into his field to determine the extent of storm damage. Finding that the bolls on some stalks suffered only slight damage, it occurred to him to develop a storm proof cotton. At this time, Mr. Mebane was growing what his neighbors called good cotton and they frequently bought planting seed from him. 'This care in the selection of cotton seed turned to his advantage in his efforts to develop a storm proof cotton. Mr. Mebane took careful note of the kind of stalk that bore the bolls that held their lint and from the best fruited stalks, he selected the finest bolls.

The next year, Mr. Mebane established on his farm the breeding plot and maintains it to this day. This breeding plot is the subject of much flowery dissertation from some who in years recent have followed in the wake of Mr. Mebane in originating varieties of cotton. Mr Mebane with his breeding plot was a pioneer in cotton improvement and development, but he was not doing a John the Baptist businesspreparing the way for another, because the "ONE MIGHTIER THAN HE" has not as yet come after him. Establish a breeding plot he did, and moreover gave his days and nights to it. Selections from the breeding plot were planted in next year's plot, while the bulk of the seed was planted to itself and next year used to plant the farm. Even before the first seed from the breeding plot was planted in the fields, Mr. Mebane realized that to attain the best results he should preserve a record of each boll planted in his breeding plot, so he began the laborious work of writing a description to be placed in the paper bag with each boll selected. The amount of data preserved with the boll increased as Mr. Mebane's work enlarged. Later the stalk from which the boll was picked is described, the position of the boll on the stalk, the per cent of lint and length and quality. To determine the lint per cent the seed and the lint of each boll are weighed on small scales.

It was not many years after Mr. Mebane began to breed for storm proof cotton that other desirable qualities became evident. His fields of cotton presented a different appearance and at the gin his loads "thirded themselves" in the average of his entire farm, which was excellent in its day. Then Mr. Mebane began to make selections not only for storm proof and prolific and drouth resistant qualities, but for a higher per cent of lint. Not many years after beginning the work based on his own observations, Mr. Mebane had cultivated a thirst for greater knowledge of plant selection and plant breeding. Accordingly he bought books and began a systematic study to perfect himself for better results. He began to cross scientifically selections of his cotton with other good varieties.

In 1900 he originated the Mebane Triumph Cotton from a cross between the cotton he had developed and the Boykin and Peterkin. He accomplished this without assistance from any Agricultural Department, but through his own unceasing efforts in hybridizing and plant breeding.

\section{Description of Mebane Triumph Cotton}

Improved Mebane Triumph cotton as to plant has a strong, stocky, thrifty stalk, deep-rooted that resists drouth, with long but short-jointed limbs. It fruits from ten to twenty days earlier than other varieties of big boll cotton-and for this reason is adapted to weevil infested districts.

Bolls are large, generally contain five locks and grow close together on the limb, one in a place and not in clusters, turning downward on the stalks and for this reason the locks of cotton stay close together and do not hang out on every side of the boll as small boll cottons do. Mebane Triumph cotton makes large five lock bolls until frost. 
The points of the burrs upon the opening of the bolls turn back, making picking easy. Mebane Triumph Cotton is as near storm proof as a cotton can be. The lint holding in the burr well during the interval between opening and the picking. The seed delint easily and for this reason the variety is a favorite with ginners. The lint is hard and strong and measures from an inch and a sixteenth to an inch and an eighth in length on the upland. On strong land in seasons of abundant moisture the length frequently reaches an inch and a quarter. A field of Mebane Triumph cotton may be recognized by its evenness of growth and its adherence to the approved type of this cotton. As the land varies in fertility, the stalks become larger or smaller but on inspection they are found to present the same characteristics of growth. The seed of pure Mebane Triumph produce the desirable qualities of cotton with greater certainties than any other variety. The characteristics of Mebane Triumph cotton are established by more than a third of a century's careful breeding from selected types. Pickers prefer to pick it to any other variety, as they can pick more and there are no long stickers on the end of the bolls to hurt the fingers. Pickers have picked six hundred pounds per day of this variety. Mebane Triumph yields more seed cotton per acre than any other variety grown under the same conditions and in many instances from 50 to 200 pounds more, as is proven by actual tests by disinterested parties. The lint turnout is one of its crowning points of excellence. When picked dry and free from dirt, the lint turnout is from 39 to 42 percent with an average of 40 percent. Under favorable conditions the lint turnout is as high as 43 per cent-sometimes even 44 percen

Mr. Mebane did not cease his efforts when he originated a variety of cotton. $\mathrm{He}$ has, through the years since 1900 , been a tireless worker in developing every desirable quality in his cotton. He has been eminently successful, to such an extent in fact, that others seeing his good work have been constrained to FOLLOW therein. There may be varieties of cotton as old as Mebane Triumph, but none have been developed by as long or as careful selection, and there are none that reproduce their qualities with as much certainty. It is a compliment to Mebane Triumph that it has been the fruitful parent of many varieties of cotton. Mr. Mebane now gives his entire time to his breeding plot. He has gained a wonderful store of information about cotton by observation in all stages from the seed to the mill that turns out the finished product in cloth. He has traveled throughout the entire cotton belt and noted cotton growth under every condition of soil and climate. He acquaints himself by reading with the best thought of the age on cotton development and cotton breeding.

Agricultural Experimental Stations report that other varieties of cotton (upon which it is known great sums have been spent in order to introduce and gain them favor) can hardly be distinguished from Mebane Triumph. This is a great recommendation to Mebane Triumph in the light of the fact that Mebane Triumph was here first. Great glory moreover accrues to Mr. A. D. Mebane in that some of the originators of these varieties are renowned experts of the United States Government. Yea, verily, they "FOLLOW." Mebane Triumph Cotton is better with each succeeding year. More than a third of a century's breeding from selected types have standardised its excellent qualities. The extent to which it is grown to the exclusion of other varieties is a correct attest of its merit, for farmers are not fools. If the treatment they receive on the world's markets was even in a slight degree comparable to the intelligence with which they produce cotton, the cotton farmer would control the financial world. Farmers know the best variety of cotton and Mebane Triumph finds favor with them. 


\section{Facts Worth Knowing}

As with merchants supplying the trade and handling different grades of wares, all claim to sell the best and when pinned down to facts claim to have something "just as good," so some dealers who sell Mebane Triumph cotton seed or so-called Mebane Triumph seed all claim to be selling the best. The public has never seen advertised third year, or fourth year seed, but the advertising of such cotton seed dealers make use of the one descriptive, "PURE." When the dealer fails to tell how he came by the seed he sells, it may be generally known that they are either a long way from Mebane, badly mixed, or never were near Mebane.

There was a time when places could be found in the cotton belt of the United States which grew such poor cotton that almost any change would show improvement, and seed with the slightest trace of Mebane Triumph brought satisfactory results. That day is now past and those who desire improved seed and pay their money for the same should have them. Many farmers cannot buy the best seed and there is no objection to a dealer who sells them seed of other grades at a cheaper price if he advertises and sells them as such, but to sell a man who desires the best and pays for the best, that which is not as represented, is dishonest and criminal. The farmer who is financially able to buy high priced pure seed generally gets what he paid for. The farmer who thinks he cannot afford to pay for the best and desires to purchase a lower grade in order that he may improve upon the cotton he has been planting, is he who is most often the dupe of skillful advertising or the slick tongued traveling salesman. He frequently gets not a lower grade of seed, nor even the lowest grade, but something so mixed that it would be nearer the truth to call it by the name of whatever else it is mixed with. Some seed are sold under the name of Mebane Triumph that have not the slightest trace of that cotton in its composition-its ancestry has never been near the farm of the Originator-A. D. Mebane at Lockhart, Texas.

\section{Not How Cheap-But How Good}

The firm of A. D. Mebane Cotton Seed Company, which in its various connections is considered the Pioneer and Leader in the sale of Improved Mebane Triumph cotton seed for planting purposes of which they are exclusive growers and dealers, has enlarged the scope of its business and is better prepared to put on the market more seed and a better quality than ever before, for various reasons:

1. We have a standing order with A. D. Mebane, President of this firm, for a larger quantity of his individual growing of seed (which we furnish our growers) than any other seed concern in the country.

2. Seed from these crops enables us to place on the market a larger quantity of pure Improved Mebane Triumph seed than any other dealer or grower.

3. These seed are grown for us under contract by the best and most careful farmers, on some of the largest select black land farms within a radius of a few miles of Lockhart. No other variety of cotton has been grown on these farms for years which also insures the purity of our seed.

4. The ginning of the cotton from which these seed are obtained receives special care. Arrangements have been made with our ginners to use every precaution to avoid any possible mixing at the gins with other cotton.

5. Our crop this year consists of 8,000 acres of Improved Mebane Triumph Cotton.

There are other reasons we could mention why our seed have gained the reputation they have, but do not deem it necessary, as we stand on our own record and are pleased to refer you to any customer who has bought planting seed from us-and you will find them by the thousands in all the cotton-growing States. We do not claim to be selling the CHEAPEST, but we do know we are selling the BEST and are just telling you that "THE PROOF OF THE PUDDING IS THE EATING THEREOF," so with the farmers who have planted our seed the fact has been thoroughly demonstrated that it is far better to secure seed from first hands than to take chances on something they know nothing about. 


\section{Photographs of Some of the Breeding Plots on Farm of A. D. MEBANE, Lockhart, Texas}

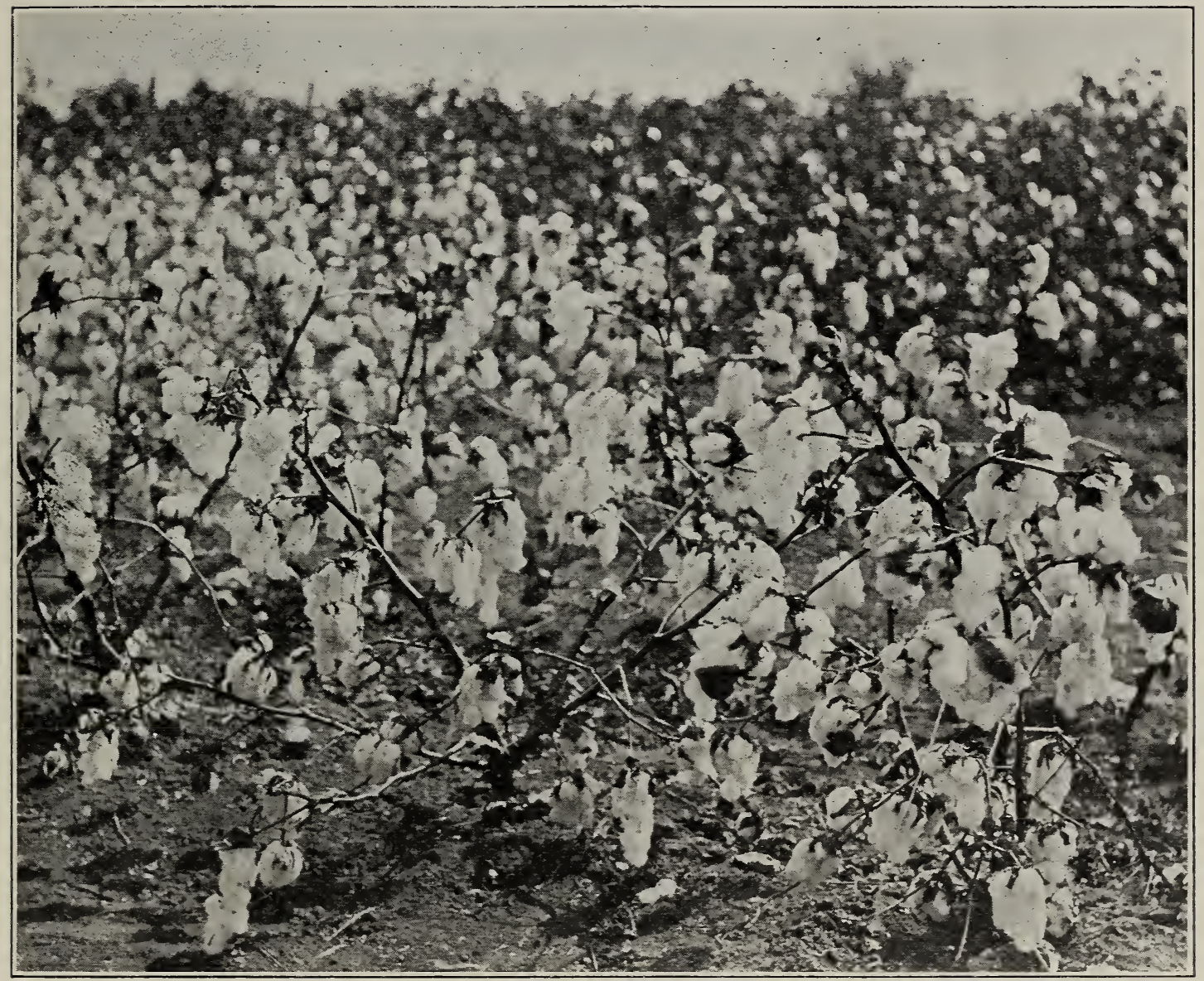

Actual Photograph of Breeding Plot No. 1, of Mebane Triumph Cotton on the farm of the originator, A. D. MEBANE, Lockhart, Texas

\section{They Speak For Themselves}




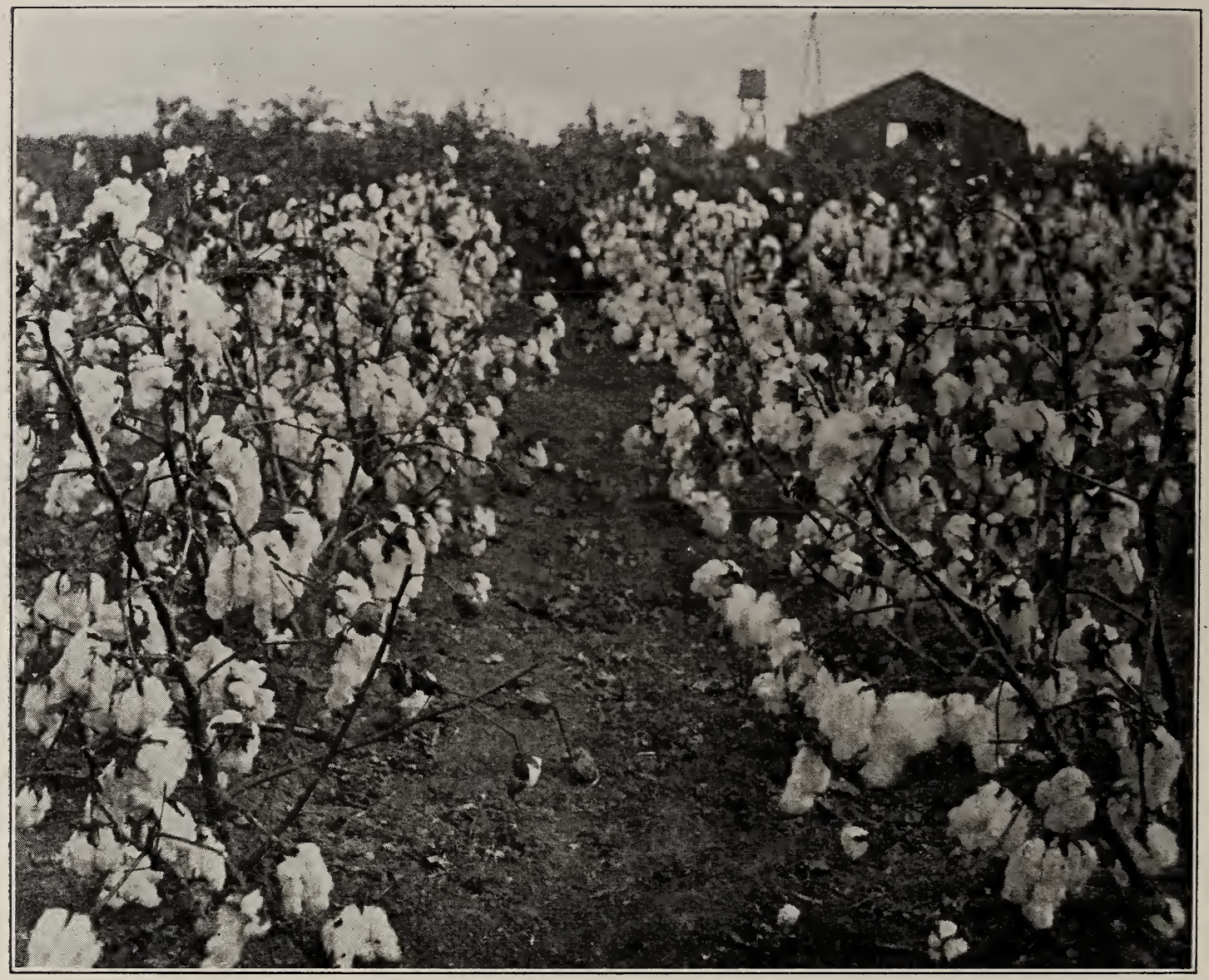

Breeding Plot No. 2, Mebane Triumph Cotton 


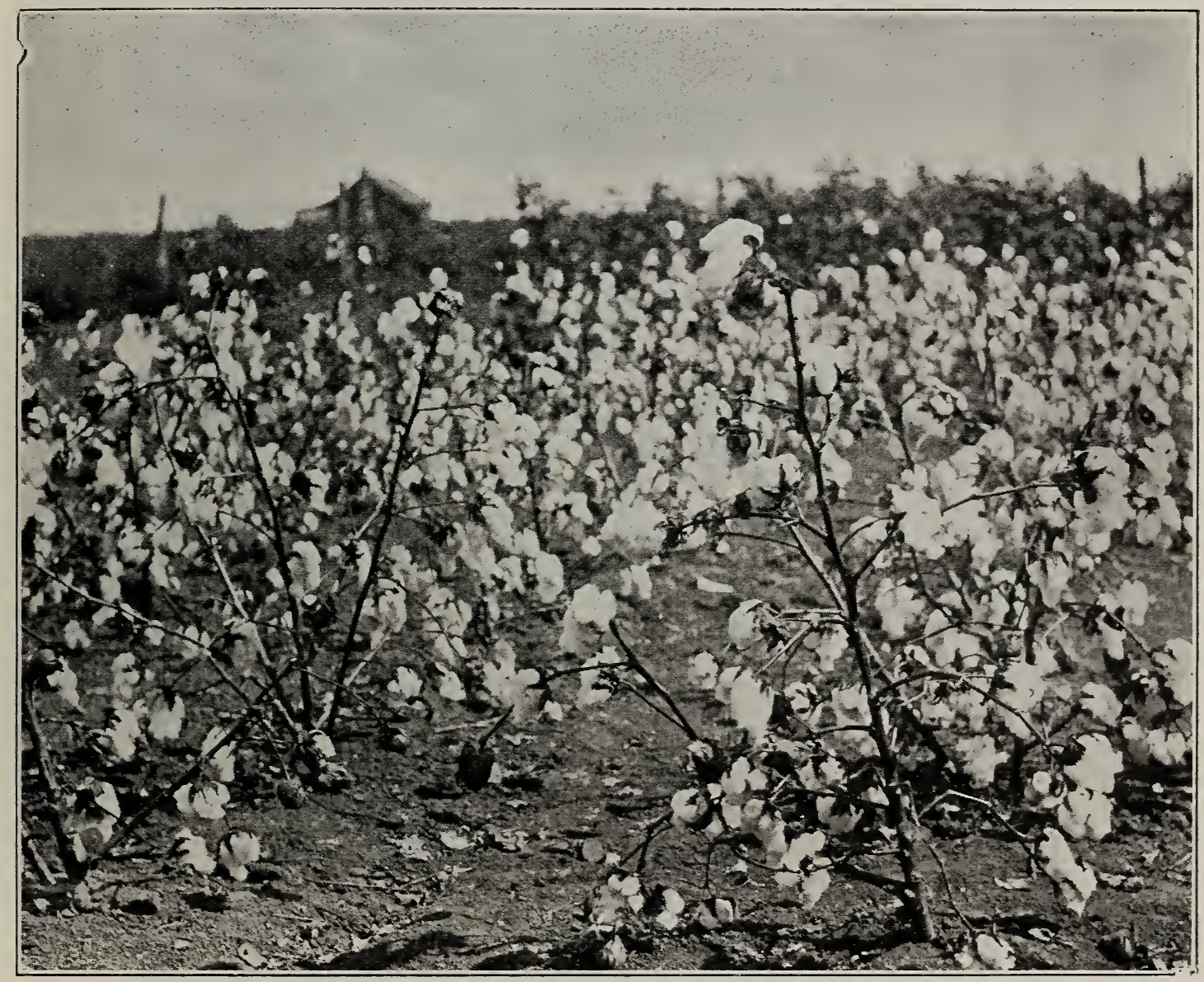

Breeding Plot No. 3, Mebane Triumph Cotton 


\section{Improved MEBANE}

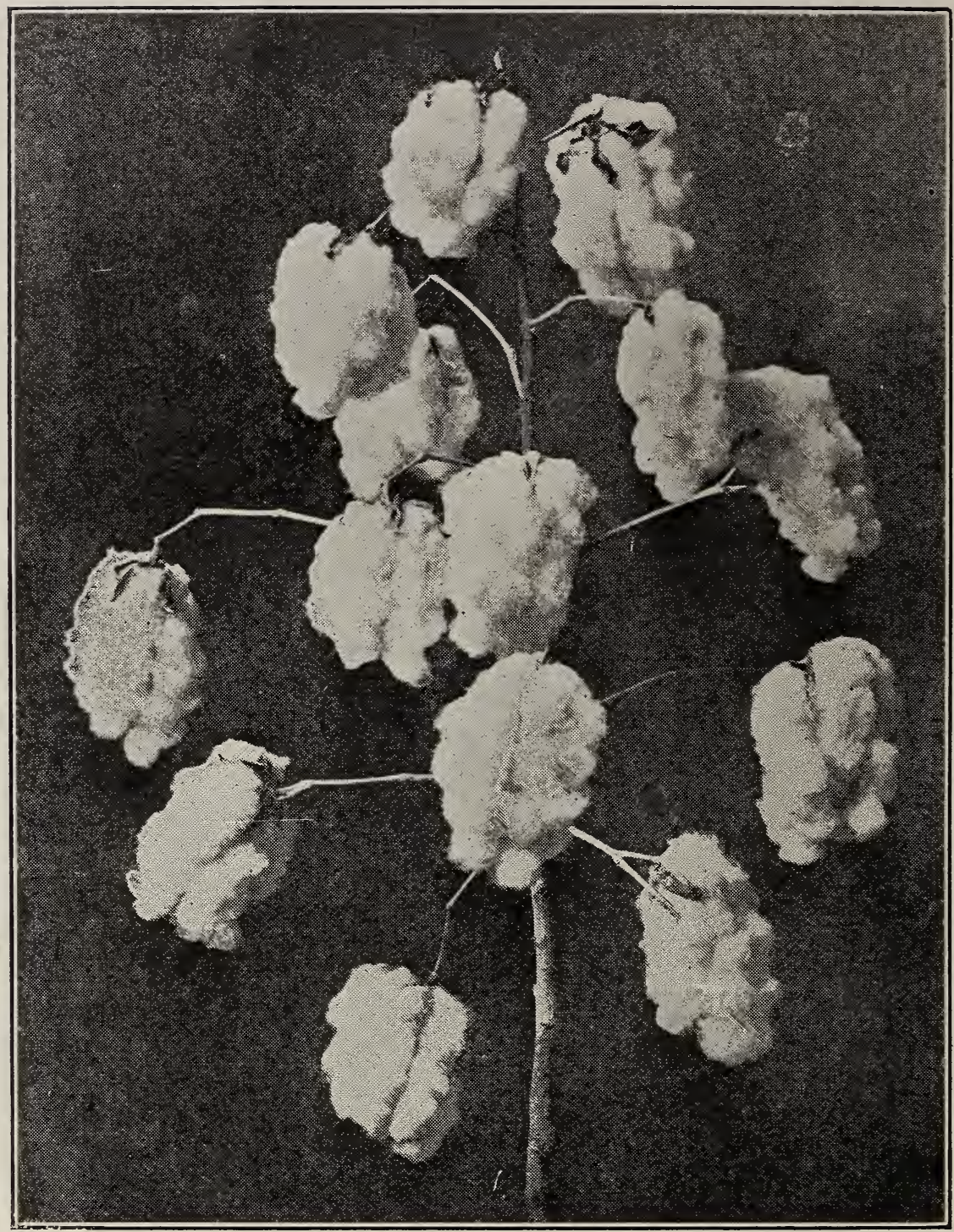

Actual photograph of a small stalk of Improved Triumph Cotton. This shows what a small stalk of this variety will produce. Only sixteen inches from the lowest limb to top of stalk.

It Can't be beat.

\section{Solves Your Future}




\section{TRIUMPH COTTON}

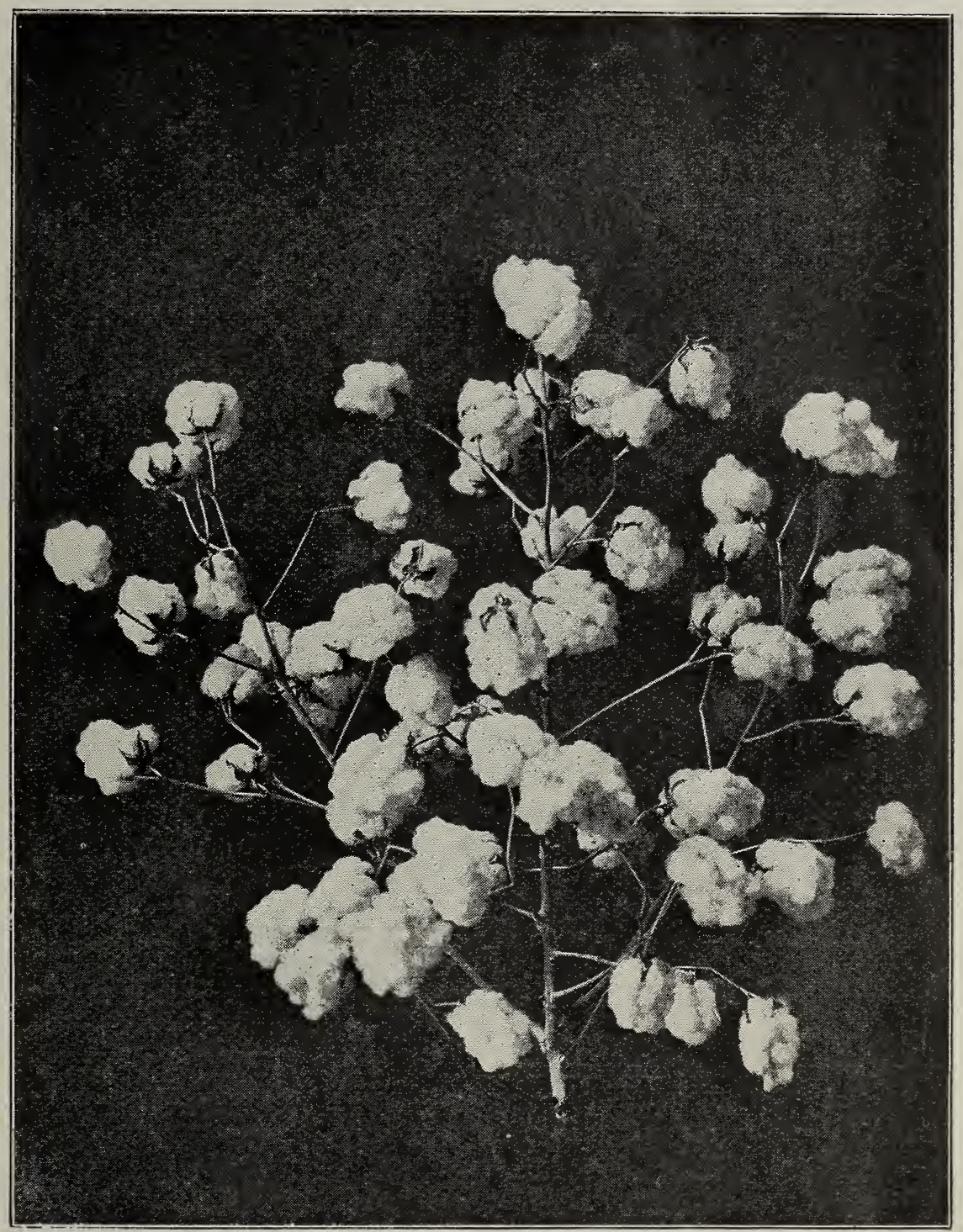

Financial Problems 


\section{Mebane Triumph Cotton Is More Extensively Grown Than Any Other Variety of Cotton}

Mebane Triumph is more extensively grown than any other variety of cotton. Ten bushels of Mebane Triumph cotton seed are planted each year to one of any other variety. The seed of Mebane Triumph are planted in almost every cotton producing area in the world. The extensive growing of this cotton is a recognition of its merit and merit to the cotton planter means no more nor less than the ability to produce profits. The lamented Dr. S. A. Knapp in his lifetime said: "The efforts of Mr. Mebane have brought millions of dollars to cotton growers." If Dr. Knapp's words needed verification, they have sufficient in the acreage each year planted to Mebane Triumph Cotton.

This tribute to Mr. Mebane comes from Bradford Knapp of the United States Agricultural Department, Washington, D. C.:

"The great mass of our people do not sufficiently appreciate the services of a man who builds up by patient selection year after year a fine variety of cotton, or the services of a man who carefully breeds live-stock. At the time the boll weevil came to Texas, it became evident that early maturing varieties of cotton were quite necessary. One of the problems was to find an early maturing variety adapted to the soil and climate which did not too greatly sacrifice length of staple. Such a variety was produced by Mr. A. D. Mebane of Lockhart. I think it was my father who first called it 'Triumph Cotton,' and it was known throughout our territory as 'Mebane Triumph.' Many of the farmers in Texas, Oklahoma, Louisiana, Arkansas, Alabama and even some of the states further east owe much to this man, who, through patient years produced this splendid cotton and especially the cotton of such splendid qualities."

This cotton has brought not alone wealth to the planter but more complete living. Their extra profits have enabled farmers to build better houses, to apply modern implements in the cultivation of their crops, to educate their children, to provide for them all of the comforts and many of the luxuries of life-making for a broader culture and a more efficient citizenship. Modern residences, macadam roads, handsome school and church edifices, and the automobile as a necessary farm vehicle have followed closely in the wake of Mebane Triumph Cotton. Not alone the men, but the women and children are the beneficiaries of its recognized merit. The results attest the truth of the words of the great Dr. Knapp: "Mebane Triumph Cotton has brought millions of dollars to the cotton farmer." Yea, it has done more, it has brought millions to women and children in redemption from drudgery and elevation to an existence worth while. The fame of Mebane Triumph has gone abroad and men seeing the advantages that have accrued to the grower have desired the seed that they may bring to themselves profits. So many have sought to supply themselves with seed of this variety that a strong demand has been created. This demand and the resultant high prices have led unscrupulous men to place on the market for pure Mebane seed that which is not. There is nothing worth while but has its counterfeit. No advantage was ever gained from honest effort but the indolent sought to gain without the labor that accompanies. 


\section{What Cotton Exporters Say}

\section{A. S. CARTER \& COMPANY COTTON \\ LOCKHART, TEXAS}

April 8, 1919.

To Whom It May Concern:

This certifies that for a number of years we have been shipping cotton from Lockhart, Texas (Mebane Cotton), to Liverpool, England, and other foreign ports, staple, $1 \frac{1}{16}$ to $1 \frac{1}{8}$ inches.

However, the past season was very dry, and with good seasons this cotton will produce full $11 / 8$.

The names of consignees can be furnished on application.

$$
\text { A. S. Carter \& Co., }
$$

\section{SOUTHERN PRODUCTS COMPANY Dallas, Texas}

Mr. W. D. Myrick,

May 9, 1919.

$$
\begin{gathered}
\text { clo Jones \& Myrick, } \\
\text { Lockhart, Texas. }
\end{gathered}
$$

\section{Dear Sir:}

We are in receipt of your letter of the 6 th with reference to the sample of cotton which you are mailing under separate cover, and have also received the sample.

We have examined it very carefully as to character and staple, and our idea of value is hard
$1 \frac{1}{6}$ inch to $11 / 8$ inch and a very desirable character of cotton for Liverpool market.

It appears to us that if any quantity of this kind of cotton can be produced in your territory it should bring a good premium over the ordinary cotton.

Very truly yours, SOUTHERN PRODUCTS Co.

VJW-LS.-File No. 690 . Per (Sig.) V. J. Wood.

\section{JONES \& MYRICK \\ COTTON \\ LOCKHART, TEXas}

To Whom It May Concern:

April 10, 1919.

This is to certify that we have shipped Mebane Cotton to New B'edford, Fall River and Boston points, staple guaranteed to be one and onesixteenth inch, and have never had a staple claim. With good seasons all of our L.ockhart cotton is one and one-sixteenth to an inch and an eighth; with the dry season we have had this past year twenty-five per cent of it has been shipped for an inch and a sixteenth.

$$
\begin{aligned}
& \text { Yours very truly, } \\
& \text { JONES \& MYRICK, } \\
& \text { By W. D. MYRICK. }
\end{aligned}
$$

P. S.-Our Mr. Myrick has had thirty (30) years' experience in the cotton business.

\section{A Statement From the Banks of Lockhart}

Lockhart, Texas, May 29, 1919.

We, the undersigned, Bankers of Lockhart, Caldwell County, Texas, in behalf of Mebane Triumph Cotton, wish to state that while other varieties of cotton have been planted in this locality and other cotton growers claim an improvement on this variety, we unhesitatingly say the Mebane Triumph Cotton originated and improved each year by A. D. Mebane is beyond a doubt the best variety for farmers to plant. It has brought more money to growers, as shown by our bank deposits, and brought more wealth to this county than all other varieties combined, and we urge cotton planters to plant this variety of cotton.

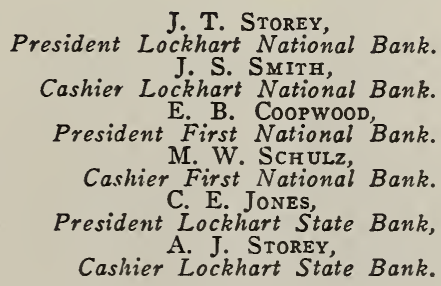


The following are extracts from letters we have received from a few parties who have thoroughly tested our Improved Mebane Triumph cotton seed, advising us of its excellency. We have numerous other letters in our files that we could publish, but do not deem it necessary, as Improved Mebane Triumph cotton stands on its own merits:

\section{Robstown, Texas, June 1, 1919.}

A. D. Mebane Cotton Seed Co.,

Lockhart, Texas.

\section{Gentlemen:}

I am writing you in the interest of your "Me bane Triumph" Cotton Seed. I have for the past several years been planting your seed on my 1,000 acre farm in Nueces County and can say that the seed have been all that I could desire them to be.

The yield has been exceptionally good and the staple (while I did not test it out) has been better than the average run of cotton planted in Nueces County and is fast becoming the cotton of that county. and South Texas.

The yield on my farm has been from onefourth to better than a bale to the acre, and while we experienced one of the worst drouths in the history of South Texas in 1917, I had cotton that produced about one-third of a bale to the acre that had less than three inches of rain from $\mathrm{De}$ cember 1st to picking time.

I cannot praise Mebane Triumph Cotton Seed too highly as a drouth resister, good staple an high acreage yield cotton. I know from experience that it will stand the test by the side of all grades of cotton that I have any knowledge of. Yours very truly,

\section{J. T. JILLETT, JR.}

Honey Grove, Texas, April 22, 1919.

A. D. Mehane Cotton Seed Company,

Lockhart, Texas.

Geutlemen:

Answering your recent inquiry, beg to advise that we have never made any exhaustive tabulations comparing the quality of Mebane Triumph cotton and other varieties, but have proven to satisfaction that Mebane gives us more net profit than any other variety we can raise.

Yours very truly, J. A. UnDFRWOOD

Pres. Honey Grove State Nat'l Bank.

Fort Smith, Arkansas, April 19, 1919.

Messrs. A. D. Mebane Cotton Seed Co.,

Lockhart, Texas.

Dear Sirs:

Replying to your letter April 14th, as regards Mebane Triumph Cotton Seed. The lint produced from your Mebane cotton is about $38 \%$ or about $2 \%$ or $3 \%$ better than the Rowden and $6 \%$ better than Native.

Will state, have sold your Mebane Triumph Cotton Seed here for a number of years and have yet to receive the first complaint. We receive many testimonials from our customers who plant your seed.

Might state, we are offered, each season, cotton seed purporting to be of this variety, by other growers at Lockhart at much lower prices, but are satisfied from what we have seen of seed shipped to our competitors, that it is not as good grade as your seed and not worth as much. I am,

Yours very truly, ARTHUR G. LEE.
A. D. Mebane Runge, Texas, October 23, 1918 Lockhart, Texas.

Gentlemien:

Am so delighted over the good turnout of: your GOOD Mebane Triumph Cotton Seed that I bought from you during my stay at the Dallas Fair in the Fall of 1917. I am sorry that I didn't buy more. From 2,100 pounds seed cotton I got 910 pounds lint, making a lint turnout of $431 / 3$ per cent.

I am sending you a few samples of the fine bolls produced from the Mebane Triumph seed bought from you.

$$
\text { Yours very truly, }
$$
lieo. Scitrade.

Bonham, Texas, April 17, 1919.

Messrs. A. D. Mebane Cotton Seed Co. Lockhart, Texas.

Gentlemen :

We have your letter of the 14 th and note contents. Our farmers plant four varieties of cotton, as follows: Mebane, Rowden, Williamson, and Eone Star. We think there are more acres planted in Mebane than any other variety and is considered the surest crop of all.

Last season was a very poor staple year for all kinds of cotton, very little going as much as $1 \frac{1}{16}$ inches. When the season is favorable Mebane will go to $11 / 8$ inches and has the reputation of making the best turn-out of all at the gin.

Respectfully,

ROgers-WOODWARD \& Roberts Co.

Ballinger, Texas, May 26, 1919.

A. D. Mebane Cotton Seed Co. Lockhart, Texas.

Gentlemen :

Ninety per cent of cotton grown in Cameron and Hidalgo Counties in 1918 was of the Mebane Triumph variety, and am sure 50 per cent was $11 / 8$ inches, balance was $1 \frac{1}{16}$ inches, staple-all good, hard cotton. A large part of this cotton was sold for export.

Yours very truly,

R. A. Nichalson.

Rogers, Texas, March 7, 1919.

Mr. Lea Beaty, Lockhart, Texas.

Dear Sir:

In reply to your letter of recent date in regards to the Lone Star cotton that was planted by the farmers at Rogers last year: Will say at least 50 per cent of the farmers planted Lone Star Every farmer that I have talked to that planted Lone Star is very much dissatisfied with it, and say there is no comparison between the Mebane Triumph and the Lone Star.

I have not heard of a man that planted Lone Star last year that will plant it this year. I don't believe there will be $2 \%$ of the farmers plant Lone Star cotton this year.

I have been buying cotton here for the past 20 years and I feel that I can tell the grade of any bale of cotton. If 10 bales of Mebane Triumph and 10 bales of Lone Star cotton, raised on the same soil and ginned on the same gin were mixed together, I or no other cotton classer could pick out the Lone Star cotton from the Mebane.

There has been no premiums paid for the Lone Star cotton in this country. Sincerely,

H. L. SKINNER. 


\section{A Statement from A. D. Mebane}

\section{TO WHOM IT MAY CONCERN :}

Frequently 'I receive communications from farmers, bankers and merchants throughout the cotton belt who are interested in buying PURE IMPROVED MEBANE TRIUMPH PLANTING CO'TTON SEED and prefer placing their order with the A. D. Mebane Cotton Seed Company rather than other seed firms, but are advised by the traveling agents of other firms that I am in no manner connected with the A. D. Mebane Cotton Seed Company, and that their firm own large farms adjacent to my farm - that their farm is planted entirely with seed purchased from me, whereby they can furnish the best seed on the market.

For the information of these people and the public generally I wish to say that my connection with the above firm has never been severed. I still remain President of that institution, retaining the same interest in it as when it was organized.

As to any seed dealer owning land adjoining my farm, there is no truth in this statement.

I have also received letters from farmers and in fact have been advised in person that unscrupulous agents traveling and selling Mebane cotton seed, have represented the seed they are selling as coming direct from my farm. In this connection I wish to advise that I have never employed agents to sell seed for me nor are they handled by outside dealers. I merely call attention of the public to this in order that they may not be misled and that they may know when Mebane Triumph cotton seed are sold under these representations-they are absolutely false and caution the public against such agents or persons making these statements.

I will appreciate your calling my attention to such occurrences, as I do not propose to tolerate any longer such misrepresentation.

Yours truly,

A. D. MEBANE. 


\section{Machine Culled Seed}

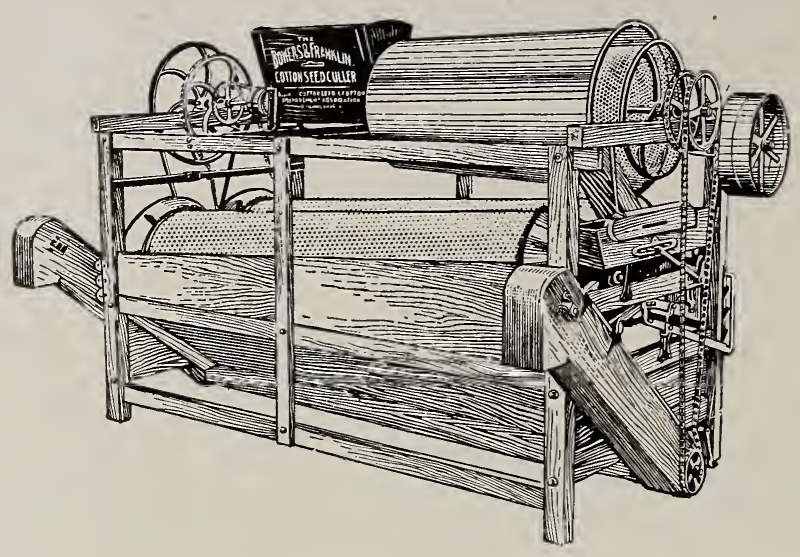

Our seed are carefully re-cleaned and culled on one of the latest Improved Machines which removes all dirt and any small seed thereby making the seed uniform in size. 


\section{Place Your Orders Early}

Transportation facilities at the beginning of the year are generally taxed beyond their capacity and in this connection we urge the mailing of orders as early as possible.

Do not wait until the rush of transportation is on, but order early and you will be spared any annoying and disasterous delay when you are ready to plant.

We can make immediate shipment, your order going forward a very few hours after reaching us.

\section{No Substitute}

When our stock of Improved Mebane Triumph planting cotton seed is exhausted we come out frankly with the statement, "SOLD OUT!" Never have we supplied our customers with the common seed we could have purchased on the open market. To serve you with the very best of seed has always been our first consideration.

Our continued success in the planting seed business is manifested by the progress we are making today.

The fact that we have been doing business in the same place for more than ten years is proof that we sell GOOD seed at right prices and that we treat our customers fairly and honestly and that we believe in the Golden Rule of "doing unto others as we would have others do unto us."

There are no degrees of honesty-a dealer sells pure seed or he does not. There is only one way to secure reliable seed and that is to secure them from a house that has its reputation behind its goods.

QUALITY and PURI'TY are the two essential things that every seed purchaser should investigate- this makes us pin our faith stronger and stronger to QUALI'TY, the basis of our continued growth.

During the past four seasons we have done the largest business since the organization of this company, and this regardless of depressed conditions. Each season we have been obliged to return to customers Money Orders and Checks by the hundreds received with orders for our Improved Mebane Triumph seed-which we could not fill on account of the great demand for our seed having exhausted our supply. There is a reason-"QUALITY." 


\section{A Word of Warning}

A great many innocent people in buying Mebane cotton seed just because the bags bear the name, "MEBANE COTTON SEED," are under the impression that the seed they are buying are direct from the A. D. Mebane Cotton Seed Co.

For the guidance of those who are desirous of securing our seed let us warn you to be sure that the bags containing the seed are branded as represented below. Every bag of cotton seed put up by us is so stenciled.

Ask your dealer in your town for seed from the A. D. Mebane Cotton Seed Co., and if he does not handle them direct from us, then write us and we will gladly furnish you prices on any quantity you may need.

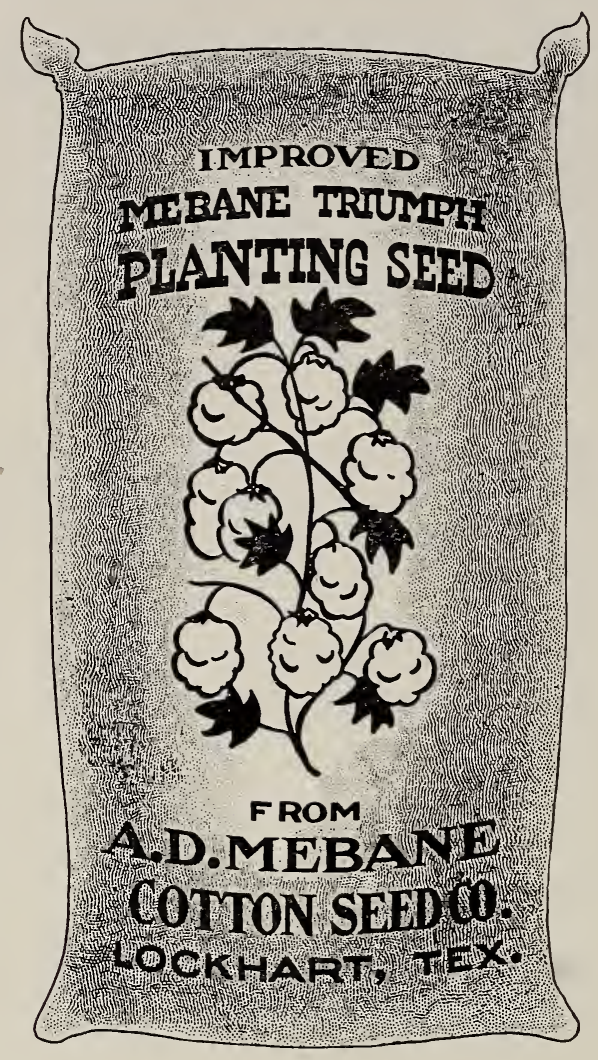

We wish to call the attention of our friends and patrons to the fact that the A. D. Mebane Cotton Seed Co. is in no way connected with any other firm or seed company handling Mebane cotton seed in the city of Lockhart, Texas, or elsewhere.

Mr. A. D. Mebane, the President of this firm, is the Originator of Mebane Triumph Cotton.

Please see that your communications are plainly addressed to

\section{A. D. MEBANE COTTON SEED COMPANY}

LOCKHART, TEXAS

MEMBER FOOD ADMINISTRATION'S CERTIFIED SEED DEALERS OF TEXAS.

Certificate No. 66 Issued November 14, 1918. UNITED STATES 

ARTHUD G. LEE,

SLED MEPUHANT FORI SMITH, - NE 